\title{
Service Quality, Perceived Value and Customer Satisfaction as determinant of Airline choice in Nigeria
}

\author{
Mukarramah Modupe Adeola ${ }^{1, *}$, Sulaimon Olanrewaju Adebiyi ${ }^{2, * \star}$ \\ 1Department of Economics and Financial Studies, Fountain University, Osogbo, Nigeria \\ ${ }^{2}$ Department of Business Administration, Federal University of Agriculture (FUNAAB), \\ Abeokuta, Nigeria \\ *,**Email: dupsyn2007@yahoo.com , lanre18april@gmail.com
}

\begin{abstract}
The success of airlines depends majorly on the ability to identify customers' wants and needs, and factor it in the quality service that would meet customers' satisfaction. Thus, there is need for continuous research so as to assist all the players survive in the changing business environment.This paper examines service quality, perceived value and customer satisfaction as the determinant of choice of airline by air travellers in Nigeria. Survey method was employed using primary data obtained through the use of questionnaires. 220 questionnaires were administered by the researcher through purposive sampling to air travellers at MM2 in Lagos which 200 were returned and properly filled. The questionnaires were analysed using descriptive statistics, correlation and regression with the support of SPSS 17. The study revealed that the income/social status, poor states of roads as well as the insecurity accounts for the sudden rise in air transport travellers and that service quality, perceive value influences their satisfaction level on the choice of airline. Therefore, airline companies in Nigeria should increase the quality of service since many users of the air transport requires it and make sure passengers fare paid should commensurate the service delivered so as to enhance travellers patronage.
\end{abstract}

Keywords: Service quality; Perceived value; Customer satisfaction; Airline industry; Nigeria

\section{INTRODUCTION}

Air transport is the transportation of passengers and cargo by aircraft and helicopters. Thus, it is a transport mode for the movement or carriage by air of persons or goods using airplanes and helicopters (Don- Beliner 1996). The airline industry is a major player in the world economy as it contributes significantly to the leisure/tourism and is a key element of international business (Tiernan, Rhodes \& Waguespack, 2008), with global airline revenues exceeding $\$ 12.9$ billion as at 2006 (IATA, 2007).

The aviation industry in Nigeria is a major player in the economy owing to its substantial contribution to ease of movement within the country especially in the face infrastructural decay (poor and insecure road transport system) in the recent years. Nigerian Airways was established in October, 1958 as a joint venture between the Nigerian government's lines and the British Overseas Airways Corporation (BOAC) while the Nigerian Airways took over the operation of domestic flights from the disbanded West African Airways Corporation (WAAC) which had 
been operating commercial aircraft within the country since 1946 (Filani, 1983). In 1963, the Nigerian Federal Government bought out the other shareholders and the Nigerian government became the sole-owner of Nigeria Airways. The airline has monopoly for providing domestic air services in Nigeria and also the national flag carrier for international services. According to Filani (1983), in 1976, within Nigeria several charter companies joined the Nigeria Airways to operate additional flight in small aircraft from Lagos to the main economic centres in the Southern and Northern parts of the country. The Nigerian government realizing the role of air transport in the Nation's development made significant attempts to develop the country's aviation industry. The most massive was the 1975-1980 airport development programme in which the Murtala Mohammed airport complex was about complex was about N240 million (Filani, 1983). Six other airports in Kano, Ilorin, Kaduna, Sokoto, Port Harcourt and Maiduguri were developed to accommodate large aircrafts. Apart from these airports development programme the Federal government also intensifies manpower development in the aviation industry. But due to the efficiency of the sector, the aviation industry was liberalized to allow private owners to compete favourable in the business.

This lead increase of number of operators and perceived frequent flyers in the industry which does the perceived services value and quality often reflect the customers' level of satisfaction with the airline and show intention to repatronize the service (FMA, 2012). According to Nigerian Airport Authority (FMA, 2012), from visiting family and friends to shipping high value products, 8.3 million passengers and 181,000 tonnes of freight travelled to, from and within Nigeria; domestically, more than 66,800 flights make over 75 million seats available to passengers, destined to 18 airports as at years 2011 and 2012.

Since success of airlines in Nigeria will be its ability to identify customers' wants and needs, gather them up and then come up with quality service that would meet customers' satisfaction it important that researches on assessing the determinant of choice of airline should be continuous as this will assist all the stakeholders survive in their strive to supress competition by attempting to bridge the existing gap between customers' service expectations and the quality of service offered by them to fly within Nigeria.

In Nigeria, the value of consumer benefit varies because of how often they fly, and the value a passenger attach to additional flight will in general fall. This is consonance to the law of diminishing returns which states that affirming that to continue after a certain level of performance has been reached, will result in a decline in effectiveness (Case, Karl \& Fair Ray (1999). Hence, this study examines if the Nigerian Passengers that fly within Nigeria get the value of the expected fare paid for the flight, fully satisfied with the services delivered or the air fee exceeds the perceived value gotten from the flight and with the less value or satisfaction gotten through air transport, some Nigerians still choose the air transport as a preferred means of transportation to move within Nigeria.

The objective of the study is therefore to:

1) identify reasons for sudden rise in air travelling among passengers in Nigeria.

2) examine how the passengers' socio-economic status affects choice of airline.

3) analyse the impact of perceived value on customer satisfaction in Nigeria Aviation Industry.

4) analyse the impact of service quality on customer satisfaction in Nigeria Aviation Industry. 


\section{LITERATURE REVIEW}

\section{1. The Concept of Service Quality}

In order for a company's offer to reach the customers there is a need for services. These services depend on the type of product or service rendered and it differs in the various organizations. Service can be defined in many ways depending on which area the term is being used. An author defines service as "any intangible act or performance that one party offers to another that does not result in the ownership of anything" (Kotler \& Keller, 2009). Service quality is considered very important indicator towards customer satisfaction (Spreng \& Machoy, 1996). Although the definitions of service quality vary, the definitions are all formulated from the customer perspective: that is, what customers perceive are important dimensions of quality (Lewis, 1989).

Airline service quality is different from services in other industries. An airline service comprises tangible and intangible attributes. Airlines carry passengers to the destination using aircraft, and passengers experience diverse intangible services from airlines such as on time performance, inflight service, service frequency and so on. Shostack (1977) asserted that airline travel is intangible-dominant. It does not yield physical ownership of a tangible good. While airline management thought frequent flyer plans and reservation systems were contributing factors in creating differentiation and customer loyalty, service quality was the fundamental issue.

The perceptions of consumers seemed to have little importance in determining the service quality measurements of airline services. While carriers experimented with service competition, similar experiments were occurring in the academic world. Service quality assessments from the perspective of the airline consumer first appeared in the doctoral dissertation work by Kearney in 1986.

The effort examined service quality from the perspective of "industry-based" economic and marketing measures including accessibility of delayed flight information, responsibility for passengers on delayed flights, attractiveness of lower fares to encourage flying during nonpeak hours, and providing enough knee and leg room, comfortable seating, pre-assigned seats, and non- stop flights (see also Kloppenborg \& Gourdin 1992, for these industry-based measures). However, such research effort overlooked the more generalized service quality work of Parasuraman, et al., (1985, 1988, and 1991).

\section{1. 1. Service Quality and Customer Satisfaction}

To achieve a high level of customer satisfaction, most researchers suggest that a high level of service quality should be delivered by the service provider as service quality is normally considered an antecedent of customer satisfaction (Cronin, Brady, \& Hult, 2000; Anderson et al., 1994; Cronin \& Taylor, 1992). Service quality and customer satisfaction became core issues for the successful survival of any service organization.

Parasuraman et al., (1994) concluded that the confusion surrounding the distinction between the two constructs was partly attributed to practitioners and the popular press using the terms interchangeable, which make theoretical distinctions difficult. Interpretations of the role of service quality and satisfaction have varied considerably (Brady et al., 2002; Cronin \& Taylor, 1992; Parasuraman, et al., (1988). Parasuraman et al. (1988)) confined satisfaction to relate to a specific transaction as service quality was defined as an attitude Since customer satisfaction has been considered to be based on the customer's experience on a particular service encounter, (Cronin \& Taylor, 1992) it is in line with the fact that service quality is a 
determinant of customer satisfaction, because service quality comes from outcome of the services from service providers in organizations.

In relating customer satisfaction and service quality, researchers have been more precise about the meaning and measurements of satisfaction and service quality. Satisfaction and service quality have certain things in common, but satisfaction generally is a broader concept, whereas service quality focuses specifically on dimensions of service. (Wilson et al., 2008). Although it is stated that other factors such as price and product quality can affect customer satisfaction, perceived service quality is a component of customer satisfaction (Zeithaml et al. 2006). This theory complies with the idea of Wilson et al. (2008) and has been confirmed by the definition of customer satisfaction presented by other researchers.

\section{2. Perceived Value}

Customer perceived value is defined as "the consumer's overall assessment of the utility of a product based on perceptions of what is received and what is given" (Zeithaml, 1988). Perceived value has its root in equity theory, which considers the ratio of the consumer's outcome/input to that of the service provider's outcome/input (Oliver \& DeSarbo, 1988). Two essential conceptions are established with customer perceived value (CPV). First, Customer Perceived value is a result from the consumers' pre-purchase perception (expectation), evaluation during the transaction (expectation versus received), and post-purchase (after-use) assessment (expectation versus received). Second, Customer Perceived Value involves a divergence between the benefits received and sacrifices given.

The benefits include customers' desired value, e.g., quality (Monroe, 1990). Sacrifices, on the other hand, include monetary (price) and non-monetary (time, effort) considerations (Cronin, et al., 2000; Dodds, Monroe, \& Grewal, 1991; Monroe, 1990). For a firm to maximize customers' perceived value, it must either increase the customers' perceived value, e.g., quality, and/or decrease their sacrifice, e.g., price paid, time and effort to purchase. Perceived value is critical to the success of buyer-seller relationships (Lemon, Rust, \& Zeithaml, 2001), e.g., customer loyalty, and consists of "the consumer's overall assessment of the utility of a product based on perceptions of what is received and what is given" (Zeithaml, 1988), or the benefits received and the sacrifices made (given).

\section{2. 1. Perceived Value and Customer Satisfaction}

Customer satisfaction, in turn, is hypothesized to be influenced by perceived value. Perceived value, as it has been defined herein, is the ratio of benefits received from providers relative to the costs sacrificed by customers. In essence, it is a variable that reflects the net utility derived from a provider. Customer satisfaction, meanwhile, is defined as an overall positive or negative feeling about the net value of services received from a supplier (Woodruff, 1997). Woodruff (1997) argues that perceived value represents customer cognition of the nature of relational exchanges with their suppliers, and satisfaction reflects customers' overall feeling derived from the perceived value.

\section{3. Customer Satisfaction}

Customer-centred companies have emphasized a better understanding of customer's needs and wants and then translated them into the capability to give customers what they really need and want. When a consumer/customer is contented with either the product or services it is termed satisfaction. Satisfaction can also be a person's feelings of pleasure or disappointment that results from comparing a product's perceived performance or outcome with their 
expectations (Kotler \& Keller, 2009). As a matter of fact, satisfaction could be the pleasure derived by someone from the consumption of goods or services offered by another person or group of people; or it can be the state of being happy with a situation. Customer satisfaction is the key factor determining how successful the organization will be in customer relationships Reichheld, 1996; therefore it is very important to measure it. Satisfaction is defined as an emotional post-consumption response that may occur as a result of comparing expected and actual performance (disconfirmation), or it can be an outcome that occurs without comparing expectations (Oliver, 1996). Satisfied customers are more likely to return to those who have helped them, and dissatisfied customers are more likely to go elsewhere next time. The key to organizational survival is the retention of satisfied customers. If companies want to achieve customer satisfaction, they must measure it, because "you cannot manage what you cannot measure" (Ho, 1995). According to Zairi (2000) the feeling of pleasure and expectation fulfilment is known as Satisfaction. If the product will not satisfied customer feelings they will be dissatisfied, and if product satisfied them after the use customer will be satisfied and become loyal to that product or brand. In other words customer satisfaction is goods or services which fulfil the customer expectation in terms of quality and service for which he paid.

Customer satisfaction in airline operations has become critically important and Dennett, Ineson, Stone, \& Colgate, (2000) suggest that as competition created by deregulation has become more in-tense, service quality in the airline industry has also received more attention. Most airlines began to offer various incentives, such as the frequent flyer programmes, in an effort to build and maintain the loyalty of customers (Miller and Hotz, 1993). Airline companies also attempted to differentiate their services through the use of computerized reservation systems which were also designed to create customer loyalty in the distribution channels (Lee and Cunningham, 1996). However, despite the airlines' efforts to differentiate their services, an extensive survey of frequent fliers conducted by Ott (1993) revealed that consumers did not perceive any difference from one carrier to another. Ostrowski et al. (1993) noted that when all airline companies have comparable fares and matching frequent flyer programs, the company with better perceived service will draw passengers from other carriers.

Airlines in Nigeria have much role to play in meeting the expectations of passengers as they serve as the bedrock of success of the Aviation industry. According to him, the more people fly, the more the revenue for the company as well as the regulatory authority. Quality is a major determinant of customers' buying behaviour as shown in the review, thus organisations focused on satisfying customers' demands adopt measures through which the demands and expectations of customers are met. This is in order to remain competitive while ensuring that the organisation remains profitable.

\section{METHODOLOGY}

\section{1. Research Design}

This study is descriptive as well as analytical. The sample population of the study were air travellers in Lagos because it has the major airports in Nigeria; Muhammed Murtala Airport II. Most Nigerians travel through Lagos when transporting by air and Lagos has the highest population than other states which provides Lagos with highest air passengers in Nigeria. The sampling survey was purposive random sample since the respondents cut across the entire Lagos airport surrounding. A total of 220 questionnaires were distributed to the air travellers in Lagos while 200 were duly returned and filled appropriately to suite the study. The questionnaire was structured for this research and was administered to Nigerian travellers for 
the aim of the study; which includes the service quality, perceived value and customer satisfaction. The survey questionnaire consisted of two sections.

The first section of the questionnaire dealt with personal and demographic characteristics of respondents which were expected to be correlated with perceptions of service quality and usage of airline travel information. Questions in the second section asked respondents questions related to the subject on the basis of the research objectives. This was measured using the likert scale and industry-based items on 5-point bipolar scales from "strongly agree" to "strongly disagree. In addition to perceived quality or satisfaction measures, behavioural intention to repatronize the airline was measured through a question, "I will use the same airline the next time I fly" on the same 5-point scale.

Questions in the questionnaire were collected from different literature sources and were adjusted to conform to the study objectives. The questionnaire was personally administered by the researchers to ensure timely filling and return. This led to majority of the questionnaire being returned. 200 of the questionnaires were correctly filled and returned, translating into 90.0 per cent response rate. The data for the study was analyzed using the SPSS 17.0 computer software and the hypotheses were tested with Pearson Product Moment Correlations and also confirmed the acceptance or rejection of the result with t-test of statistics.

\section{2. Research Hypothesis}

Consequently the proposed hypothesis of the study is;

$\mathrm{H}_{01}$ : There is no significant relationship between service quality and satisfaction of air travellers Nigeria.

$\mathrm{H}_{1}$ : There is significant relationship between service quality and satisfaction of air travellers Nigeria.

$\mathrm{H}_{02}$ : There is no significant relationship between perceived value and air travellers' satisfaction in Nigerian.

$\mathrm{H}_{2}$ : There is no significant relationship between perceived value and air travellers' satisfaction in Nigeria.

$\mathrm{H}_{03}$ : Socio economic attribute of airline travellers do not influence the choice of airline.

$\mathrm{H}_{3}$ : Socio economic attribute of airline travellers does influence the choice of airline.

\section{3. Research Instrument Validity and Reliability}

Reliability regards to the consistency of the results obtained from instruments used in the research. Reliability is an assessment of the degree of consistency between multiple measurements of a variable (Pallant, 2004). Validity is the degree to which a measure accurately represents what it is supposed to (Hair et al., 2007). Validity determines the extent to which a scale measures a variable of interest.

Cronbach's alpha was used to assess the internal consistency of the entire scale. According to Pallant (2004), reliability scores greater than 0.70 are acceptable and Nunnaly (1978) has indicated 0.7 to be an acceptable reliability coefficient but lower thresholds are sometimes used in the literature. As all of the items had an alpha above the standard guideline of 0.70 , the scales are suitable for analysis with acceptable reliability. The Cronbachs' alpha were computed for the following measures of the variables in this study, these are; Reason for the sudden rise in air travelling in Nigeria, factors that affects choice of airline to fly, socioeconomic factors of traveller, impact of service quality on customer satisfaction and impact of perceived value on customer satisfaction using the Statistical Packages for social science (SPSS). All the measures of the study exceeded the acceptable alpha. 
Table 1. Reliability of Questionnaire.

\begin{tabular}{|c|c|c|}
\hline Variables & No. of Items & Cronbachs' alpha \\
\hline $\begin{array}{c}\text { Reason for sudden rise in air } \\
\text { transport }\end{array}$ & 8 & 0.734 \\
\hline $\begin{array}{c}\text { Factors that affect choice of airline } \\
\text { to fly within Nigeria }\end{array}$ & 7 & 0.726 \\
\hline Socio-economic factors of traveller & 5 & 0.735 \\
\hline Service quality & 6 & 0.765 \\
\hline Perceived value & 4 & 0.786 \\
\hline
\end{tabular}

Table 1 shows different Cronbach's Alpha value for the 5 constructs of the questionnaire ( 1 dependent variable and 4 independent variables). The factors that affect choice of airline to fly within Nigeria has the lowest Alpha of 0.726 , followed by reasons for sudden rise in air transport with 0.734, Socio-economic factors of traveller with 0.735 , the impact of service quality on customer satisfaction with 0.765 and the impact of perceived value on customer satisfaction with the highest alpha of 0.786 . Overall, this indicates that there is internal consistency of the entire variables scale and that variables construct exhibited strong internal reliability. The results, therefore, confirmed that the instrument used for this study had satisfactory construct validity.

\section{ANALYSIS}

The Table 2 below describes the Frequency distribution of respondents by demographic status.

Table 2. Summary of Frequency distribution of respondents by demographic status.

\begin{tabular}{|c|c|c|}
\hline Variables & Frequency & Percentage (\%) \\
\hline Gender & & \\
\hline Male & 123 & 61.5 \\
\hline Female & 77 & 100 \\
\hline Total & 200 & 3.0 \\
\hline Age & 6 & 30.5 \\
\hline below 21yrs & 61 & 39.5 \\
\hline $21-30 y r s$ & 79 & 20.0 \\
\hline $31-40 y r s$ & 40 & 7.0 \\
\hline $41-50 y r s$ & 14 & 100 \\
\hline 51 and above & 200 & \\
\hline Total & & \\
\hline & & \\
\hline Marital Status & & \\
\hline
\end{tabular}




\begin{tabular}{|c|c|c|}
\hline Single & 80 & 40.0 \\
\hline Married & 117 & 58.5 \\
\hline Divorced & 1 & 0.5 \\
\hline Widowed & 2 & 1.0 \\
\hline Total & 200 & 100 \\
\hline \multicolumn{3}{|l|}{ Religion } \\
\hline Islam & 49 & 24.5 \\
\hline Christianity & 149 & 74.5 \\
\hline Others & 2 & 1.0 \\
\hline Total & 200 & 100 \\
\hline \multicolumn{3}{|l|}{ Educational Status } \\
\hline Secondary & 3 & 1.5 \\
\hline $\mathrm{NCE} / \mathrm{ND}$ & 8 & 4.0 \\
\hline Bsc & 138 & 69.0 \\
\hline Others; Post Graduate & 51 & 25.5 \\
\hline Total & 200 & 100 \\
\hline \multicolumn{3}{|l|}{ Occupational status } \\
\hline Employed & 150 & 75.0 \\
\hline Self-employed & 30 & 15.0 \\
\hline Job seeker & 12 & 6.0 \\
\hline Others; student & 8 & 4.0 \\
\hline Total & 200 & 100 \\
\hline \multicolumn{3}{|l|}{ Income } \\
\hline Below 89999 & 22 & 11.0 \\
\hline $90000-199999$ & 34 & 17.0 \\
\hline $200000-399999$ & 26 & 13.0 \\
\hline $400000-599999$ & 30 & 15.0 \\
\hline 600000 -above & 88 & 44.0 \\
\hline Total & 200 & 100 \\
\hline \multicolumn{3}{|l|}{ Travel by air } \\
\hline Yes & 189 & 94.5 \\
\hline No & 11 & 5.5 \\
\hline Total & 200 & 100 \\
\hline \multicolumn{3}{|l|}{ Frequent traveller } \\
\hline Weekly & 14 & 7.0 \\
\hline Monthly & 51 & 25.5 \\
\hline Yearly & 53 & 26.5 \\
\hline Others specified & 82 & 41.0 \\
\hline Total & 200 & 100 \\
\hline \multicolumn{3}{|l|}{ Last trip reason } \\
\hline Business & 102 & 51.0 \\
\hline Education & 17 & 8.5 \\
\hline Tourism & 42 & 21.0 \\
\hline Religion & 6 & 3.0 \\
\hline Others specified & 33 & 16.5 \\
\hline Total & 200 & 100 \\
\hline
\end{tabular}




\begin{tabular}{|c|c|c|}
\hline Airline class & & \\
\hline Economy & 140 & 70.0 \\
\hline Business & 55 & 27.5 \\
\hline First class & 5 & 2.5 \\
\hline Total & 200 & 100 \\
\hline Airline & & \\
\hline Aero contractors & 86 & 43.0 \\
\hline Arik & 54 & 27.0 \\
\hline Dana & 7 & 3.5 \\
\hline Air Nigeria & 2 & 1.0 \\
\hline Multiple airlines & 51 & 25.5 \\
\hline Total & 200 & 100 \\
\hline
\end{tabular}

Source: Field Survey, 2013

It was observed from the result that $61.5 \%$ of the respondents of the questionnaires were male while $38.5 \%$ were female in this category of air travellers. Respondents between the ages of 31-40 years were observed to be more than other groups as they constituted $39.5 \%$, this was closely followed by ages of 21-30 years with 30.5\% of the respondents. The ages 41-50 and 50 and above were of $20 \%$ and $7 \%$ respectively while the respondents below 21 years of age constitute the smallest fraction as observed among the air travellers with a percentage $3 \%$. The marital status that was mostly observed was of that of the married respondents with a percentage of $58.5 \% .40 \%$ of respondents were also observed to be single/not yet married, 0.5 $\%$ and $1 \%$ of the respondents were divorced and widowed respectively.

The religion status of air travellers was also observed that Christian respondents were with a percentage of $74.5 \%$, followed by Muslims with a percentage of $24.5 \%$ and $1 \%$ of the respondents were others respectively. High level of education was witness among the air travelers with $69 \%$ were graduates. $25.5 \%$ of the respondents specified educational level above graduate education likes $\mathrm{M}$. Sc, MA and PhD. $4 \%$ and $1.5 \%$ were NCE/ND and secondary school holders. Most of the respondents were engaged under one form of paid employment or the other with $75 \%$ of the total respondents under paid employment. $15 \%$ of the respondents are on self-employment while $6 \%$ and $4 \%$ were unemployed and others such students.

From the distribution of the respondents, all of them receive monthly income by one means or the other. With $44 \%$ of them have receiving 600000 - above, $17 \%$ and $15 \%$ of the respondents receiving 90 000-199 999 and 400 000-599 999 respectively. $13 \%$ of the respondents receive 200 000-399 999 while below 89999 the least were $11 \%$. The distribution shows that $94.5 \%$ of the respondents have travelled by air while $5.5 \%$ of the respondents have not travelled by air. $41 \%$ of the respondents specified their travelling mode like quarterly, thrice in a year and when the need arises. $26.5 \%$ and $25.5 \%$ of respondents travel yearly and monthly respectively and $7 \%$ travel weekly.

The reason of most respondents' last trip was that of business reason with a percentage of $51 \% .21 \%$ of respondents' last trip was of tourism, $16.5 \%$ and $8.5 \%$ of respondents' last trip reason was specified like medical, family visit and private reason and education reason respectively, religion reason of respondents' last trip fell at a percentage of $3 \%$. Respondents that choose economy class were observed to be more than other groups as they constituted 70 $\%$, this was followed with a large gap by the business class with $27.5 \%$ of the respondents. 
While the respondents that choose first class constitute the smallest fraction as observed among the air travellers with a percentage $2.5 \%$.

High level of air travelers that patronize different airlines was witnessed among the respondents of the distribution with $43 \%$ and $27 \%$ were Aero contractors and Arik airline flyers respectively. $25.5 \%$ of the respondents patronize multiple airlines, $3.5 \%$ of the respondents fly Dana air while $1 \%$ of the respondent patronize Air Nigeria.

\section{1. Model Specification}

The specification of a model is based on the available information relevant to the objectives of the study in question. Here, the predictors are reason for rise in air transport, socio economic attributes, service quality and perceived value and the dependent variable is the factors that lead to choice of airline (customer satisfaction). The model is stated below; $\mathrm{FCOA}=\mathrm{f}\{\mathrm{PV}, \mathrm{SQ}, \mathrm{SEF}, \mathrm{RSRA}\}$

Such that;

$$
\mathrm{FCOA}_{\mathrm{t}}=\propto_{0}+\propto_{1} \mathrm{PV}_{\mathrm{t}}+\propto_{2} \mathrm{SQ}_{\mathrm{t}}+\propto_{3} \mathrm{SEF}_{\mathrm{t}}+\propto_{4} \mathrm{RSRA}_{\mathrm{t}}+\mathrm{e}_{\mathrm{t}}
$$

where;

FCOA $=$ Factors that influence the choice of airline/Customer Satisfaction

$\mathrm{PV}=$ Perceived Value

$\mathrm{SQ}=$ Service Quality

$\mathrm{SEF}=$ Socio Economic Factors

RSRA $=$ Reasons for the sudden rise air transport

$\mathrm{e}_{\mathrm{t}}=$ Error term

$\propto_{1}=$ Parameter Estimates

$\propto_{1}>0, \propto_{2}>0, \propto_{3}>0, \propto_{4}>0$.

\section{2. Regression result and interpretation}

The regression analysis results as shown in the model summary 1, in Tables 3 and 4 indicate that $32.8 \%$ of the observed variations in customer Satisfaction $\left(\mathrm{R}^{2}=0.328\right)$ is explained by perceived value, service quality, socioeconomic attributes and reasons for the rise in air transport.

Thus, perceived value, service quality, socioeconomic attributes and reasons for the rise in air transport are positively associated with factors that influence choice of airline to fly within Nigeria.

The F-value - 23.795 of statistics which is used to measure the overall significance of the model In this study, the result the probability of the F statistics gives 0.000 which means that the model is statistically significant at $1 \%$. Durbin Watson gives a value of 2.236; which is not farther than the benchmark of 2 this implies that there is a no serial correlation in the model. 
Table 3. Model Summaryb.

\begin{tabular}{|c|c|c|c|c|c|c|c|c|c|c|}
\hline \multirow[b]{2}{*}{ Model } & \multirow[b]{2}{*}{$\mathrm{R}$} & \multirow{2}{*}{$\begin{array}{c}\mathrm{R} \\
\text { Square }\end{array}$} & \multirow{2}{*}{$\begin{array}{c}\text { Adjusted R } \\
\text { Square }\end{array}$} & \multirow{2}{*}{$\begin{array}{l}\text { Std. Error } \\
\text { of the } \\
\text { Estimate }\end{array}$} & \multicolumn{5}{|c|}{ Change Statistics } & \multirow[b]{2}{*}{$\begin{array}{l}\text { Durbin- } \\
\text { Watson }\end{array}$} \\
\hline & & & & & $\begin{array}{c}\text { R Square } \\
\text { Change }\end{array}$ & F Change & df1 & $\mathrm{df} 2$ & $\begin{array}{c}\text { Sig. F } \\
\text { Change }\end{array}$ & \\
\hline 1 & $.573^{\mathrm{a}}$ & .328 & .314 & .80564 & .328 & 23.795 & 4 & 195 & .000 & 2.236 \\
\hline \multicolumn{11}{|c|}{ a. Predictors: (Constant), reasons, service, socioeconomic, perceived } \\
\hline \multicolumn{11}{|c|}{ b. Dependent Variable: factors } \\
\hline
\end{tabular}

Table 4. ANOVA ${ }^{\mathrm{b}}$.

\begin{tabular}{|c|c|c|c|c|c|c|}
\hline \multicolumn{2}{|c|}{ Model } & Sum of Squares & Df & Mean Square & F & Sig. \\
\hline \multirow{3}{*}{1} & Regression & 61.777 & 4 & 15.444 & 23.795 & $.000^{\mathrm{a}}$ \\
\cline { 2 - 7 } & Residual & 126.566 & 195 & .649 & & \\
\cline { 2 - 7 } & Total & 188.343 & 199 & & & \\
\hline \multicolumn{7}{|c|}{ a. Predictors: (Constant), reasons, service, socioeconomic, perceived } \\
\hline
\end{tabular}

Table 5. Coefficients ${ }^{\mathrm{a}}$.

\begin{tabular}{|c|c|c|}
\hline \multicolumn{2}{|c|}{ Unstandardized Coefficients } & $\begin{array}{c}\text { Standardized } \\
\text { Coefficients }\end{array}$ \\
\hline B & Std. Error & Beta \\
\hline-1.011 & .561 & \\
\hline .396 & .080 & .328 \\
\hline .305 & .120 & .162 \\
\hline .034 & .083 & .026 \\
\hline .519 & .135 & .252 \\
\hline
\end{tabular}

a. Dependent Variable: factors

Table 6. Correlations output for testing the hypothesis 1.

\begin{tabular}{|c|c|c|c|}
\hline & & SQ & CS \\
\hline \multirow{3}{*}{ SQ } & Pearson Correlation & 1 & $.225^{* *}$ \\
\cline { 2 - 4 } & Sig. (2-tailed) & & .001 \\
\cline { 2 - 4 } & $\mathrm{N}$ & 200 & 200 \\
\hline \multirow{3}{*}{ CS } & Pearson Correlation & $.225^{* *}$ & 1 \\
\cline { 2 - 4 } & Sig. (2-tailed) & .001 & \\
\cline { 2 - 4 } & $\mathrm{N}$ & 200 & 200 \\
\hline
\end{tabular}

**. Correlation is significant at the 0.01 level (2-tailed). 
Hypothesis 1: This means that there is a significant relationship between service quality and customer satisfaction. Hence accepting the alternative hypothesis $\left(\mathrm{H}_{1}\right)$ and rejecting the null hypothesis $\left(\mathrm{H}_{0}\right)$.

Table 7. Correlations output for testing the hypothesis 2 .

\begin{tabular}{|c|c|c|c|}
\hline \multirow{4}{*}{ PV } & & PV & CS \\
\hline \multirow{7}{*}{ CS } & $\begin{array}{c}\text { Pearson } \\
\text { Correlation }\end{array}$ & 1 & $.637^{* *}$ \\
\cline { 2 - 4 } & Sig. (2-tailed) & & .000 \\
\cline { 2 - 4 } & $\mathrm{N}$ & 200 & 200 \\
\hline \multirow{3}{*}{$* *$ Correlation is significant at the 0.01 level (2-tailed). } \\
\cline { 2 - 4 } & $\begin{array}{c}\text { Pearson } \\
\text { Correlation }\end{array}$ & $.637^{* *}$ & 1 \\
\cline { 2 - 4 } & Sig. (2-tailed) & .000 & 200 \\
\hline \multicolumn{2}{|c|}{$\mathrm{N}$} & 200 & 2 \\
\hline
\end{tabular}

Hypothesis 2: The alternative hypothesis $\left(\mathrm{H}_{1}\right)$ is accepted thereby leading to the rejection of the null hypothesis $\left(\mathrm{H}_{0}\right)$.

Table 8. Correlations output for testing the hypothesis 3.

\begin{tabular}{|c|c|c|c|}
\hline & & Socioeconomicfactors & Choiceofairline \\
\hline \multirow{5}{*}{ Socioeconomicfactors } & $\begin{array}{c}\text { Pearson } \\
\text { Correlation }\end{array}$ & 1 & $.213^{* *}$ \\
\cline { 2 - 4 } & Sig. (2-tailed) & & .002 \\
\cline { 2 - 4 } Choiceofairline & $\mathrm{N}$ & 200 & 200 \\
\hline \multirow{3}{*}{$* *$ Pearson } \\
\cline { 2 - 4 } & Correlation & $.213^{* *}$ & 1 \\
\cline { 2 - 4 } & Sig. (2-tailed) & .002 & 200 \\
\cline { 2 - 4 } & $\mathrm{N}$ & 200 & \\
\hline \multirow{2}{*}{$* *$ Correlation is significant at the 0.01 level (2-tailed). } \\
\hline
\end{tabular}

Hypothesis 3: This shows that there is positive and strong correlation between socio economic factors and choice of airline, which is also significant at the 0.01 level (2-tailed). This mean that the null hypothesis $\left(\mathrm{H}_{0}\right)$ is rejected thereby leading to the acceptance of the alternative hypothesis $\left(\mathrm{H}_{1}\right)$.

\section{DISCUSSION OF FINDINGS}

This study explored the determinants of service quality, perceived value, and customer satisfaction in the Nigerian aviation industry. It also examines the impact of service quality on 
customer satisfaction and the impact of perceived value on customer satisfaction on the overall performance of the Nigerian airline industry through air travellers' perceptions. The study also found that there is a positive impact between socio economic attributes of an air traveller and the choice of airline to fly within Nigeria; it was nice because some strong evidence that supports this point was established through the correlation and regression analysis. This study reveals that there is a strong relationship between reasons for the rise in air transport, socio economic factors, service quality and perceived value, with the value of $32.8 \%$ of variation in the factors that influence the choice of airline to fly within Nigeria through customer satisfaction.

This study is one such study after many years of research on service quality, perceived value, customer satisfaction and the airline industry, the preponderance of evidence indicates a positive relationship between customer satisfaction and the airline industry and also service quality and the airline industry. Their findings varied results that showed that majority of air travellers across board for all airlines are business travellers and those on official functions or duty meaning that air transportation in Nigeria is mainly used by those that do not pay their fares themselves; local airlines in Nigeria must take quality issues rather seriously as it is a major determinant of their continuous existence and this was achieved through the use of SERVQUAL. However, this study is consistent with the previous study that not only majority of people that travel by air travel for business purpose but also for other reasons like vacation, medical purpose and so on and also the SERVQUAL model was not applied in this study.

Majority of the respondents agreed on been satisfied with the airline used last and will patronize the airline the next time they fly. This in line with the fact that the quality of service is not up to expectation; there is still increase in the air transport sector. The study also revealed that the income of an air traveller affects the choice of airline to fly, with $25.0 \%$ strongly agree and $29.5 \%$ agree rate. This might be one of the reasons for the sudden rise in air transport in Nigeria. Thus, this is consistent with view of Ukpere, Mobolaji, Christopher, Callistus, \& Edem, (2012), who posited that one should expect the air travellers' income to have a significant impact particularly for stratified flights; Stratified flights are flights that involve more than one class of service in a particular aircraft for a particular flight, that is, situations where you have "economic class", "business class" and "first class" in a flight. Besides, the result found out the predictive ability of independent variable (PV, SQ, SEF, RSRA) at 0.328 on the dependent variable to be fair enough, which show that there are other factors or variables that accounted for the remaining 0.672 or $6.72 \%$ of the total factors that influence choice of airline to fly.

This study also revealed the increasing in interest in determining the sign and magnitude of any relationship that might exist between service quality and customer satisfaction in the Nigerian airline industry and its future performance to be positive and strong. Although some of the respondents indicate that they will not patronize the same airline the next time they fly but a greater percentage of the respondents will patronize the same airline the next time they fly within Nigeria. This is a clear evident the Nigerian airline industry not only relates positively to passengers, it also satisfy them positively through good service quality.

\section{CONCLUSION}

Customer satisfaction includes other things, those that benefit from the quality of service of the airline so as to patronize the industry. This will equally complement the airlines' effort at making profit. The industry should accept the reality that there exists symbiotic relationship 
between a passenger's socio economic attributes and factors that influence the choice of airline to fly.

The hypothesis revealed that a good airline service quality will lead to customer satisfaction which wills in turn increases profitability of the industry. The value of ' $r$ ' as calculated shows that there is a positive correlation between service quality and customer satisfaction. The study also recognises other factors that influence choice of airline and all other reasons for the rise in air transport. This study also concluded that Nigerian airline industry seems to be losing out since passengers complain about not been fully satisfied, patronizing the same airline because they have no choice instead of choosing an airline cause of its fine qualities. Thus, the Nigerian airline industry should improve on their operations to attract more passengers.

\section{References}

[1] Anderson E. W., Fornell C., Lehmann D. R., Journal of Marketing 58 (1994) 53-66.

[2] Cronin J. J., Brady M. K., Hult C. T., Journal of Retailing 76(2) (2000) 193-218.

[3] Cronin J. J., Taylor S. A., Journal of Marketing 56(3) (1992) 55- 68.

[4] Dodds W. B., Monroe K. B., Grewal D., Journal of Marketing Research 28 (1991) 307-319.

[5] Don-Berliner (1996). Aviation: Reaching for the Sky. The Oliver Press, inc.

[6] Ott E. (1993). Chaos in dynamical systems. Cambridge University Press, Cambridge.

[7] Federal Ministry Aviation (2012). Federal Ministry of Transport (Air). Retrieved 7 January, 2013.

[8] Filani M. O (1983). Air Transportation in Oguntoyinbo, J. S, Areola O. O, Filani M., eds A Geography of Nigerian Development second edition, Heineman Education (Nigeria).

[9] Fred Reichheld (1996). The loyalty effect: The Hidden Force behind growth, profits and lasting Value. Boston: Bain \& Company, Inc.

[10] Hair J., Black W., Babin B., Anderson R., Tatham R. (2007). Multivariate data 'analysis, 6th edition. New Jersey: Pearson Education, Inc.

[11] Ho S., (1995). TQM: An Integrated Approach. Kogan page, London.

[12] IATA (2007). New financial forecast- more cautious outlook for 2008, available at www.iata.com/economies, accessed 30 December 2012.

[13] Hotz. J., Robert A. Miller, Review of Economic Studies 60 (1993) 497-539.

[14] Karl F. Case, Fair Ray (1999), Principles of Economics, 5th Edition. Prentice Hall.

[15] Kent. B. Monroe (1990), Pricing: making profitable decisions. New York: McGrawHill.

[16] Kloppenborg Timothy J., Kent N. Gourdin (1992). Up in the Air About Quality, Quality Progress, February, 31-35

[17] Mohammed Zairi, An international Journal 7(4) (2000) 239-246.

[18] Nunnally J. C. (1978). Psychometric theory, 2nd edition. New York: McGraw-Hill. 
[19] Oliver R. L. (1996). Satisfaction: A behavioural perspective on the consumer, McGrawHill, New York, NY.

[20] Ostrowski P. L., O’Brien T. V., Gordon G. L. Journal of Travel Research 32(2) (1993) $16-24$.

[21] Pallant J. (2004). SPSS Survival Manual, London. Open University Press, McGraw-Hill.

[22] Parasuraman A., Zeithaml V. A., Berry L. L., Journal of Retailing 64 (1988) 12-40.

[23] Parasuraman A, Zeithaml V, Berry L., Journal of Marketing 49 (1985) 41-50.

[24] Parasuraman A., Berry L. L., Zeithaml, V. A., Journal of Retailing 67(4) (1991) 420-450.

[25] Phili. L. Kottler, Kevin. L. Keller (2009), Marketing Management, 13th edition. Pearson Education/Prentice Hall.

[26] Shostack G. L., Journal of Marketing 41(2) (1977) 414-434.

[27] Spreng R. A., Mackoy R. D., Journal of retailing 722 (1996) 201-14.

[28] Tiernan S. Rhoades, D. L, Waguespack B., Managing Service Quality 18(3) (2008) 212-224.

[29] Wilfred I. Ukpere1, Mobolaji S. Stephens, Christopher C. Ikeogu, Callistus. C. Ibe, Edem O. P. Akpan, African Journal of Business Management 6(15) (2012) 5442-5455.

[30] Woodruff R. B., Journal of the Academy of Marketing Science 25 (1997) 139-153.

[31] Zeithaml V. A., Journal of Marketing 52 (1988) 2-22.

[32] Zeithaml V. A., Bitner M. J. (1996). Services marketing. New York: McGraw- Hill. 